\title{
In Vitro Evaluation of Dermanyssus Gallinae Response to Products in Aqueous Suspension
}

\author{
Daniele Mallmann \\ Universidade do Vale do Taquari \\ Flávio Renato Silva \\ Médico-Veterinário, Salvador do Sul / RS \\ Noeli Juarez Ferla \\ Universidade do Vale do Taquari \\ Guilherme Liberato da Silva \\ Universidade do Vale do Taquari \\ Liana Johann \\ Universidade do Vale do Taquari
}

Angelica Sulzbach ( $\square$ angelicasulzbach@gmail.com )

Universidade do Vale do Taquari https://orcid.org/0000-0002-2309-4025

\section{Research Article}

Keywords: resistance, ectoparasites, aviculture, poultry health

Posted Date: May 7th, 2021

DOI: https://doi.org/10.21203/rs.3.rs-484416/v1

License: (c) (i) This work is licensed under a Creative Commons Attribution 4.0 International License. Read Full License

Version of Record: A version of this preprint was published at Experimental and Applied Acarology on February 10th, 2022. See the published version at https://doi.org/10.1007/s10493-022-00697-9. 
1 In vitro evaluation of Dermanyssus gallinae response to products in aqueous suspension

2 Angelica Sulzbach ${ }^{\mathrm{a} *}$, Daniele Mallmann ${ }^{\mathrm{a}}$, Flávio Renato Silva ${ }^{\mathrm{b}}$, Noeli Juarez Ferla ${ }^{\mathrm{a}}$, Guilherme Liberato

3 da Silva ${ }^{a}$, Liana Johann ${ }^{a}$

4

$5 \quad{ }^{1}$ Laboratório de Acarologia, Tecnovates, Universidade do Vale do Taquari - Univates, Lajeado, 95914-

6 014, Rio Grande do Sul, Brasil

$7 \quad{ }^{2}$ Médico-Veterinário, Salvador do Sul/ RS

8 *Corresponding Author - Angelica Sulzbach - Av. Avelino Talini, 171, prédio 21, sala 106 - Bairro

9 Universitário, Lajeado/RS - Brasil | CEP 95914-014. E-mail: angelicasulzbach@gmail.com

10

11 ORCID

12 Angelica Sulzbach - (ORCID ID 0000-0002-2309-4025)

13 Daniele Mallmann - (ORCID ID 0000-0002-2212-1044)

14 Noeli Juarez Ferla - (ORCID ID 0000-0003-0771-6864)

15 Guilherme Liberato da Silva - (ORCID ID 0000-0001-6619-6622)

16 Liana Johann - (ORCID ID 0000-0002-7105-9806)

\section{Abstract}

Dermanyssus gallinae are hematophagous mites that pose a serious sanitary problem in the Brazilian laying poultry industry. Its control is typically performed with acaricides, either in powder or liquid form. However, the intensive use of these products has led populations of this species to develop resistance. The aim of the present study is to evaluate the response of $D$. gallinae eggs and adults to products in aqueous suspension as per the commercial indication and registered at the Ministry of Agriculture, Livestock, and Supply. The study used four different acaricides (Product 1- Cypermethrin, Chlorpyrifos, and Piperonyl Butoxide; Product 2 - Alkyl-benzyl-dimethyl ammonium chloride, glutaraldehyde, deltamethrin; Product 3 - Dichlorvos; Product 4 - Fluralaner) tested in vitro using the contact method. Distilled water was used in the control group. There was difference between eggs and adults in each treatment $(p<0.05$, except for control); products had higher efficacy against adult forms. This result might be directly related to frequent D. gallinae reinfestations in poultry houses.

30 Keywords: resistance; ectoparasites; aviculture; poultry health 


\section{Introduction}

Arthropods are a threat to the poultry industry due to their direct and indirect effects on bird health and well-being (Sparagano et al. 2009). Hematophagous mites are one of the obligatory ectoparasites of domestic, wild, and laying hens (Oliveira 2017), and are considered to be the best adapted to their vectorial role; some species are vectors of pathogen microorganisms (Valiente-Moro et al. 2005).

The control of ectoparasites is essential for maintaining biosafety of poultry farm systems, as lack of control maximizes risks of occurrence of sanitary issues, thus resulting in economic problems (Faleiro 2012). Intensive production inside poultry houses increases the risks of epidemics, reduces egg quality, and causes yield to drop. Therefore, preventive sanitary measures limit the propagation of vectors, and the lack of these measures allows the introduction and dissemination of diseases in poultry farms (Borne and Comte 2003).

Commercial laying hens have been affected by mite infestations in Brazil for a long time (Rezende et al. 2013; Faleiro et al. 2015; Horn et al. 2016). One of the species that threaten the hen population is Dermanyssus gallinae (De Geer, 1778) (Mesostigmata: Dermanyssidae), a hematophagous mite that poses a serious sanitary problem for the laying poultry industry (Cunha et al. 2009). Its effects on the production and health of birds places it among the ectoparasites with the greatest economic relevance to egg production worldwide (Chauve 1998).

Dermanyssus gallinae might cause irritation, anemia, blood-stained eggs, aggressive behavior, cannibalism, and in some severe cases, even the death of laying hens (Chauve 1988; Sparagano et al. 2009; Cunha 2013; Flochlay et al. 2017; Oliveira 2017). It is also related to low yield, decreased egg quality, and host unbalance, which causes this species to be deemed as pest, owing to the economic damages it causes to the poultry industry (Oliveira 2017). The high number of specimens of this hematophagous mite in poultry houses with recurring Salmonella infections also raises the issue of the potential role played by $D$. gallinae as a vector for this disease (and other diseases) in poultry farms (Valiente-Moro et al. 2007; Moro et al. 2009; Sparagano et al. 2014). They spend the majority of their life cycle away from the host, sucking blood mostly during the night. When they are not feeding, they form colonies in cracks and crevices that are used as hiding places (Cunha et al. 2009; Pereira 2011). Adults of this species might survive away from hens without feeding for several months, which explains their persistence in poultry houses (Taylor et al. 2007), either because they remain inside the poultry facility nearly throughout their cycle (Tucci et al. 2008) or because their control is hampered by their resistance to products (Harrington et al. 2011).

Once D. gallinae populations are established, control is typically performed with acaricides, in either powder or liquid form. However, due to food safety regulations, the options for controlling this mite are somewhat limited (Brännström et al. 2008). The most frequently used products are organochlorines, organophosphates, pyrethroids, and carbamates (Marangi et al. 2008; Sparagano et al. 2009; Benítez et al. 2011; Abbas et al. 2014; Sparagano et al. 2014). Their repeated used for long periods of time, as well as their incorrect application or application without a clear management program, or even the use of illegal chemical acaricides (off-label) have led D. gallinae to develop resistance to these compounds, which often renders their efficacy uncertain (Marangi et al. 2008; Sparagano et al. 2009; Sparagano et al. 2014; Abbas et al. 2014; Gay et al. 2020). Control is also hampered because these mites hide in inaccessible places, due 
to their ability to remain long periods (up to one year) without feeding and to their high fertility (Cencek et al. 2011). Therefore, the aim of the present study is to evaluate the response of D. gallinae eggs and adults to products in aqueous suspension as per commercial indication and as registered at the Ministry of Agriculture, Livestock, and Supply.

\section{Materials and Methods}

\section{Experimental design}

Mites were collected in a commercial laying poultry house situated in the municipality of Salvador do Sul - RS, inserted in plastic bags, which were sealed and taken to Laboratório de Acarologia/Tecnovates/Univates, where they were screened. After screening, specimens were maintained in plastic bags and stored at ambient temperature until the experiment was performed.

Four different acaricides (Table 1) in aqueous suspension were used in the present study, tested in vitro through the contact method, according to the amount of product per area predicted in their labels. The total volume applied per arena was $0.5 \mathrm{ml}$ of prepared solution. Distilled water was used in the control group. Dermanyssus gallinae adults and eggs were used in the test, and the methodology used was adapted from Alves et al. (2019).

Table 1: Tested products, their components, and dosage indicated by the manufacturer's label:

\begin{tabular}{|c|c|c|c|c|c|}
\hline $\begin{array}{l}\text { Product } \\
\text { (composition) }\end{array}$ & Class & $\begin{array}{l}\text { Action } \\
\text { mode* }\end{array}$ & $\begin{array}{l}\text { Pests and } \\
\text { diseases }\end{array}$ & $\begin{array}{l}\text { Dosage } \\
\text { indicated by } \\
\text { the } \\
\text { manufacturer } \\
\text { (for mite } \\
\text { control) }\end{array}$ & $\begin{array}{c}\text { Dosage applied by } \\
\text { arena }\end{array}$ \\
\hline $\begin{array}{l}\text { Product 1 } \\
\text { (Cypermethrin, } \\
\text { Chlorpyrifos, } \\
\text { and Piperonyl } \\
\text { Butoxide) }\end{array}$ & Ectoparasiticide & - & $\begin{array}{c}\text { Alphitobius } \\
\text { diaperinus (lesser } \\
\text { mealworm) and } \\
\text { Dermanyssus } \\
\text { gallinae (chicken } \\
\text { lice) }\end{array}$ & $\begin{array}{l}\text { Broth: } 1 \text { liter of } \\
\text { product diluted } \\
\text { in } 400 \text { liters of } \\
\text { water. } \\
\text { Application: } 1 \\
\text { liter of broth for } \\
\text { each } 1.2 \mathrm{~m}^{2} \text { to } \\
\text { be treated. }\end{array}$ & $\begin{array}{l}0.5 \mathrm{ml} \text { of broth } \\
\text { containing } 5.87 \mu \mathrm{l} \\
\text { of product. }\end{array}$ \\
\hline $\begin{array}{l}\text { Product } 2 \\
\text { (Alkyl-benzyl- } \\
\text { dimethyl } \\
\text { ammonium } \\
\text { chloride, } \\
\text { glutaraldehyde, } \\
\text { deltamethrin) }\end{array}$ & $\begin{array}{l}\text { Insecticide - } \\
\text { Acaricide } \\
\text { Disinfectant: } \\
\text { bactericide, } \\
\text { Virucide and } \\
\text { fungicide }\end{array}$ & - & $\begin{array}{c}\text { Dermanyssus } \\
\text { gallinae (chicken } \\
\text { lice) } \\
\text { Insects (Musca } \\
\text { domesticae - flies, } \\
\text { lesser mealworm, } \\
\text { and lice); bacteria; } \\
\text { viruses, and fungi. }\end{array}$ & $\begin{array}{l}\text { Broth: } 300 \mathrm{ml} \text { of } \\
\text { product diluted } \\
\text { in } 100 \text { liters of } \\
\text { water. } \\
\text { Application: } 1 \\
\text { liter of broth for } \\
\text { each } \mathrm{m}^{2} \text { to be } \\
\text { treated. }\end{array}$ & $\begin{array}{l}0.5 \mathrm{ml} \text { of broth } \\
\text { containing } 8.45 \mu \mathrm{l} \\
\text { of product. }\end{array}$ \\
\hline$\frac{\text { Product } 3}{\text { (Dichlorvos) }}$ & Insecticide & $\mathrm{C} / \mathrm{I} / \mathrm{F}$ & $\begin{array}{c}\text { Cockroaches, fleas, } \\
\text { thumbtacks, } \\
\text { woodworm beetles, } \\
\text { ants } \\
\text { Crawling, flying } \\
\text { insects, and stored } \\
\text { product pests. }\end{array}$ & $\begin{array}{l}\text { Broth: } 5 \mathrm{ml} \text { of } \\
\text { product diluted } \\
\text { in } 1 \text { liter of } \\
\text { water. } \\
\text { Application: } 1 \\
\text { liter of broth for } \\
\text { each } 20 \mathrm{~m}^{2} \text { to be } \\
\text { treated. }\end{array}$ & $\begin{array}{l}0.5 \mathrm{ml} \text { of broth } \\
\text { containing } 0.702 \mu \mathrm{l} \\
\text { of product. }\end{array}$ \\
\hline
\end{tabular}




\begin{tabular}{|c|c|c|c|c|c|}
\hline$\frac{\text { Product } 4}{\text { (Fluralaner) }}$ & $\begin{array}{l}\text { Acaricide } \\
\text { Insecticide }\end{array}$ & $\mathrm{S}$ & $\begin{array}{l}\text { Poultry mites } \\
\text { Dermanyssus } \\
\quad \text { gallinae }\end{array}$ & $\begin{array}{l}0.5 \mathrm{mg} \\
\text { Fluralaner per } \\
\mathrm{kg} \text { of hen body } \\
\text { weight. The } \\
\text { product is } \\
\text { diluted in hen } \\
\text { water. }\end{array}$ & $\begin{array}{l}0.5 \mathrm{ml} \text { of broth } \\
\text { containing } 0.25 \mu \mathrm{l} \\
\text { of product. }\end{array}$ \\
\hline
\end{tabular}

86 Source: Elaborated by the author (2020).

87 *Action mode: C - contact / I - ingestion / S - systemic / F - Fumigation

88 _ Manufacturer does not provide information in product instructions

\section{Experimental Unit}

91

The arenas used were comprised of Petri dishes $\left(\mathrm{a}=28.26 \mathrm{~cm}^{2}\right)$ with qualitative filter paper discs $\left(80 \mathrm{~g} / \mathrm{m}^{2}\right)$ at the bottom and vaseline on the edges. Vaseline was used as a barrier, to prevent mites from escaping (Alves et al. 2019).

Ten D. gallinae adults were distributed on each arena. Five replicates/treatment were performed, with 0.5 $\mathrm{ml}$ of broth sprayed on each replicate, using a professional SW-775 airbrush (working pressure 10 to 45 psi) at a distance of $15 \mathrm{~cm}$ inside an Exhaust Cabin. After drying under ambient conditions, the dishes were sealed with plastic wrap and maintained in a climate chamber at $25 \pm 1^{\circ} \mathrm{C}, 70 \pm 5 \%$ relative humidity, and 14 hours photophase (Alves et al. 2019).

Mites were evaluated on a daily basis for five days using a Leica stereoscope microscope (S6E - LED 2500) (Leica Microsystems, Germany), and were considered dead if no movement was visible after touching them with the fine-tipped brush.

In order to evaluate ovicidal activity, the same procedure was repeated with $D$. gallinae eggs, with $0.5 \mathrm{ml}$ of broth applied to each dish. Five replicates were performed for each treatment and for the control. Evaluations were performed on a daily basis for five days, by counting the number of eggs hatched, and live and dead mites by observation under a stereoscopic microscope.

\section{Data analysis}

In order to calculate mortality, the following formula was used:

$$
\text { Mortality }(\%)=\text { sum of mites } x 100 / \text { total mites }
$$

Corrected mortality of adults and eggs, on the other hand, was calculated using Abbott's formula (1925), where Mt is Total Mortality, Mc is Corrected Mortality relative to control, and Mo is the observed mortality in each treatment (Silva et al. 2007; Locher et al. 2010).

$$
M c=\{[(M o-M t) /(100-M t)] \times 100\}
$$

Acaricide lethal activity was classified according to Kim et al. (2007), where mortality > 80\% is considered strong, $80-61 \%$ is moderate, $60-40 \%$ is weak, and mortality $<40 \%$ is considered little or no activity. 
116

117

118

119

120

121

122

123

124

125

126

127

128

129

130

131

Mean corrected mortalities of adults and eggs in the treatments were compared statistically using KruskalWallis non-parametric test, followed by Student $t$-test, with significance of $\mathrm{p} \leq 0.05$. Corrected mortalities against adults and eggs using each pesticide tested were compared using the Mann-Whitney test, with significance of $\mathrm{p} \leq 0.05$. All tests were performed using Bioestat 5.0 (Ayres et al. 2007).

\section{Results}

Effects on adults

Corrected mortality was significant for all products tested (Table 2). Products 2 (Alkyl-benzyl-dimethyl ammonium chloride, glutaraldehyde, deltamethrin), 3 (Dichlorvos), and 4 (Fluralaner) had 100\% of mortality up to the 5th day. Product 1 (Cypermethrin, Chlorpyrifos, and Piperonyl Butoxide), on the other hand, had $97.5 \%$ of mortality. Following Kim et al. (2007), the lethal activity of all products tested was considered strong, as it was $>80 \%$. There was no significant difference between treatments $(p>0.05)$; however, all treatments were different from the control sample $(\mathrm{p}<0.05)$.

Table 2: Corrected mortality of Dermanyssus gallinae adults and eggs after spraying the products tested, and lethal activity against adults (Kim et al. 2007).

\begin{tabular}{lccc}
\hline Product & Eggs & Adults & $\begin{array}{c}\text { Lethal activity against } \\
\text { adults }\end{array}$ \\
\hline$\underline{\text { Product 1 }}$ & $21.39 \pm 25.77 \mathrm{abB}$ & $97.5 \pm .5 .59 \mathrm{aA}$ & $>80 \%$ - Strong \\
$\underline{\text { Product 2 }}$ & $39.44 \pm 22.86 \mathrm{aB}$ & $100 \pm .0 \mathrm{aA}$ & $>80 \%$ - Strong \\
$\underline{\text { Product 3 }}$ & $47.78 \pm 27.61 \mathrm{aB}$ & $100 \pm .0 \mathrm{aA}$ & $>80 \%$ - Strong \\
$\underline{\text { Product 4 }}$ & $14.44 \pm 4.35 \mathrm{abB}$ & $100 \pm .0 \mathrm{aA}$ & $>80 \%-$ Strong \\
$\underline{\text { Control }}$ & $0 \mathrm{bA}$ & $0 \mathrm{bA}$ & -- \\
(water) & & &
\end{tabular}

132

133

134

135

136

137

138

139

140

141

142

143

144

Source: Elaborated by the author (2020).

* Means inside the same column followed by the same lowercase letter are not significantly different ( $\mathrm{p}$ > $0.05)$.

*Means inside the same row followed by the same uppercase letter are not significantly different ( $\mathrm{p}>$ $0.05)$.

Effects on D. gallinae eggs

After spraying the products tested, the corrected mortality (nonviability) of eggs was $21.39 \%$ with the first product tested (Cypermethrin, Chlorpyrifos, and Piperonyl Butoxide); 39.44\% with Product 2 (Alkylbenzyl-dimethyl ammonium chloride, glutaraldehyde, deltamethrin); and $47.78 \%$ with Product 3 (Dichlorvos). Product 4 (Fluralaner) had the lowest egg nonviability after treatment application; $14.44 \%$. 44 Products 1, 2, 3, and 4 had no significant difference from each other $(p>0.05)$. However, products 2 and 3 
145 differed from the control sample $(\mathrm{p}<0.05)$. There was difference between eggs and adults in each treatment

146 ( $<<0.05$, except for control), indicating a higher efficacy of the products against adult forms.

\section{Discussion}

148 Dermanyssus gallinae can be found throughout the year (Sparagano et al. 2014), and its life cycle (egg to 149 egg) can be completed in up to 7 days under optimal conditions (Chauve 1998). Poultry houses are 150 considered sites with suitable conditions for the growth and development of populations of this species, 151 with temperatures ranging from $10^{\circ} \mathrm{C}$ to $35^{\circ} \mathrm{C}$, and relative humidity higher than $70 \%$ (Nordenfors et al. 152 1999; Sparagano et al. 2014).

The results obtained here showed that the products tested were not efficient against both $D$. gallinae life stages (eggs and adults) evaluated in the present study. Product 1, made of Cypermethrin, Chlorpyrifos, and Piperonyl Butoxide had a strong lethal activity $>80 \%$ (Kim et al. 2007) against adults. However, there was a significant difference between eggs and adults. Considering that hens cannot be inside the poultry house during spraying (Ouro fino 2020), the low efficacy of the product against D. gallinae eggs might become an even greater issue, as mites of this species might have already established new populations once the hens repopulate the house. Additionally, D. gallinae might survive long enough to infest a new flock, especially because they may live up to several months without feeding (Chauve 1988; Sparagano et al. 2014).

Regarding Product 1 formulation, both cypermethrin and chlorpyrifos are widely used to control arthropods and animal parasites. Chlorpyrifos is an inhibitor of acetylcholinesterase (AChE) affinity. The action mechanism of cypermethrin, on the other hand, occurs via sodium channel blockade. Cypermethrin and Piperonyl Butoxide are classified as synthetic pyrethroids, are their efficacy is due to synergy of their active principles (Beckel et al. 2006; Oliveira-Sequeira et al. 2014; Campos et al. 2017). However, the variation used in hens and evaluated in the present study indicated D. gallinae egg resistance.

It is worth noting that in some studies, e.g., Ambwani et al. (2018), even low doses of cypermethrin caused immunotoxicity, oxidative stress, and apoptosis of poultry lymphocytes. When its toxicity is taken into consideration, the effects of this compound are deemed as detrimental (Eraslan et al. 2017). Data such as these show the importance of the correct application of products, without the presence of hens and observing the specified withholding period, especially at sites populated by animals that shall be used subsequently for human consumption.

The second product tested (Product 2) is an Alkyl-benzyl-dimethyl ammonium chloride-, glutaraldehyde-, and deltamethrin-based disinfectant/insecticide. The disinfectant effect of this compound is due to benzalkonium chloride and glutaraldehyde. Deltamethrin, on the other hand, is part of the group of pyrethroids, which are synthetic adaptations of pyrethrins and which provide excellent knockdown, despite their low residual activity due to their instability (Casida 1983; Taylor 2001; Abbas et al. 2014). Similar to 
181

182

183

184

185

186

187

188

189

190

191

192

193

194

195

196

197

198

199

200

201

202

203

204

205

206

207

208

209

210

211

212

213

214

215

216

217

218

The compound (Product 2) was effective against $100 \%$ of adults that underwent the treatment $(100 \pm 0)$. Hence, its lethal activity was considered strong $>80 \%$ (Kim et al. 2007). However, its action was significantly different against eggs, with a nonviability of $39.44 \%$. D. gallinae resistance to pyrethroids has already been widely reported and observed in the United Kingdom and European countries such as Italy, France, and Sweden (Mul et al. 2009; Sparagano et al. 2014). Thomas et al. (2018) also reported apparent resistance of D. gallinae to deltamethrin, which is present in Product 2, as well as to Cypermethrin, present in Product 1.

The composition of the third product tested (Product 3) is based on dichlorvos, an organophosphate that, similar to other insecticides of its class, acts by inhibiting acetylcholinesterase (AChE) function, which consequently affects the transmission of nervous impulses and leads ultimately to pest paralysis and death (Taylor 2001). Organophosphates were pioneers among chemical groups used for the control of arachnids, which include bird mites (Beesley 1963; Abbas et al. 2014). Despite that, studies such as Nordenfors and Höglund (2000) have already mentioned the limited effect of organophosphates, with only temporary suppression of mite populations.

After it was applied in vitro to D. gallinae, the product had a strong lethal activity and mortality of $100 \%$ on adults. These findings corroborate Beugnet et al. (1997), who found that dichlorvos was effective against D. gallinae adults. Nevertheless, despite its efficacy against adults, our results showed that the dichlorvosbased treatment had a significant difference against eggs, as $47.78 \%$ of them were nonviable. On the other hand, this product had higher nonviability of egg hatching than the other products tested in the present study.

The last product tested, comprised of Fluralaner (Product 4), showed strong lethal activity against adults, reaching corrected mortality of $100 \%$. When applied to eggs, its efficacy was not the same, with only $14.44 \%$ of nonviable eggs; this number was the least significant among the treatments tested against eggs in the present study.

It is important to consider that the mode of action of Fluralaner is different from any other poultry acaricides. This product acts systematically and its administration occurs via drinking water. Once it is ingested by the hen, Fluralaner inhibits parts of the mite nervous system, leading to paralysis and death (Thomas et al. 2018).

Working with D. gallinae, Thomas et al. (2018) tested three different methods using Fluralaner: one corresponding to spray application, used for traditional contact acaricides; an immersion test; and a feeding test. According to the authors, Fluralaner was active in the three tested methods, although the highest activity was reported in the feeding treatment. This study counted only adults of the species, and eggs were not evaluated.

Although the availability of this type of product has decreased in many countries due to legislation (Sparagano et al. 2014), D. gallinae control in current poultry production systems is difficult to achieve without the use of chemical products of any kind (Taylor 2001; Abbas et al. 2014). However, these chemical compounds have been suffering drawbacks such as mite resistance and concerns with human, animal, and environmental health (Taylor 2001). 
In many countries, the use of synthetic products has been increasingly limited due to a progressively stricter legislation regarding components and their impacts. The restraints to the use of these products also include egg withholding periods or restrictions that prevent treatments from occurring with the presence of hens inside poultry houses, in order to mitigate risks of residues in the products, and consequently, minimize risks to human health (Roy et al. 2009; Sparagano et al. 2014).

\section{Conclusions and Perspectives}

The data provided here show that, although the products evaluated were effective against $D$. gallinae adults, their efficacy was not the same against eggs under the same conditions. This finding might be directly related to frequent $D$. gallinae reinfestations in poultry houses, corroborating the initial hypothesis that $D$. gallinae is resistant to the products tested, which are frequently applied in laying poultry houses.

According to Beugnet et al. (1997), reinfestation in poultry houses occurs four to eight weeks after acaricidal treatments, which might be related to treatment failure, rapid parasite reproduction, short period of time without hens in the poultry house, or even resistance to the products. The present study corroborates this information, as mites of this species showed resistance to the products tested.

Data such as these indicate the need for further studies and for improving these products and their components (Taylor 2001), as well as the need for studies that focus on the biological control of this species, using either microorganisms or predators. It is worth emphasizing that the data shown here report a laboratory situation, where products are applied directly on the area with the mites under evaluation. In poultry houses, it is harder for products to come into direct contact with mites, especially due to the large number of cracks and crevices that exist at these sites, which work as hiding places for this species (Nordenfors and Höglund 2000).

Since developing resistance to these ectoparasites might lead to concerning effects on poultry farm systems and affect their economic viability (Beugnet et al. 1997), further studies considering the efficacy of products also against larvae and adults derived from treated hatched eggs are recommended, as well as field tests in order to confirm the acaricidal activity of these compounds in these environments.

\section{Acknowledgments}

The authors are grateful to Universidade do Vale do Taquari - Univates for their financial support and for providing the material required to conduct this study.

Funding information No specific funding is associated with this case report.

Author contributions AS, LJ, GLS and FRS designed the study; AS, DM, performed research, laboratory activities; AS, LJ, GLS, NJF and FRS contributed to diagnosis and writing; AS, LJ and GLS drafted the paper with contributions from all other authors.

Data availability All data and materials are available for publication.

\section{Compliance with ethical standards}

Conflict of interest The authors declare no conflict of interest. 
254

255

256

257

258

259

260

261

262

263

264

265

266

267

268

269

270

271

272

273

274

275

276

277

278

279

280

281

282

283

284

285

286

287

Ethical approval All applicable international, national, and/or institutional guidelines for the care and use of animals were followed.

Consent to participate All authors participated voluntarily in the research.

Consent for publication All authors read and approved the final manuscript.

\section{References}

Abbas RZ, Colwell DD, Iqbal Z, Khan A (2014) Acaricidal Drug Resistance in Poultry Red Mite (Dermanyssus gallinae) and Approaches to Its Management. Worlds Poult Sci J 70: 113-24. doi:10.1017/S0043933914000105.

Abbott WS (1925) A Method of Computing the Effectiveness of Insecticide. J Econ Entomol 18: 265267.

Alves LFA, Oliveira DGP, Kasburg CR, Nardelli MS (2019) Acaricidal activity of inert powders against the poultry red mite Dermanyssus gallinae (De Geer, 1778) (Mesostigmata: Dermanyssidae). Arch Vet Sci 24: 81-92. doi:10.5380/avs.v24i2.62775.

Ambwani S, Ambwani TK, Singh R (2018) Immunotoxic effects of cypermethrin in mitogen stimulated chicken lymphocytes due to oxidative stress and apoptosis. J Entomol Zool Stud 6: 37-42.

Ayres M, Ayres Junior M, Ayres DL, Santos ADAD (2007) BioEstat: aplicações estatísticas nas áreas das ciências biomédicas. Ong Mamiraua. Belém, PA.

Beckel HS, Lorini I, Lazzari SMN (2006) Efeito do Sinergista Butóxido de Piperonila na Resistência de Oryzaephilus surinamensis (L.) (Coleoptera, Silvanidae) a Deltametrina e Fenitrotiom. Rev Bras Entomol 50: 110-114.

Beesley WN (1963) The effect of three organo-phosphorus insecticides on certain arthropods which infest livestock. Ann Appl Biol 52: 295-303. doi:10.1111/j.1744-7348.1963.tb03751.x.

Benítez V, García C, Gargallo D, Catalá-Gregori P (2011) Eficácia in vitro de diferentes productos contra Dermanyssus gallinae. In XLVIII Simposio Científico de Avicultura, WPSA-AECA 5.

Beugnet FC, Chauve M, Gauthey, Beert L (1997) Resistance of the Red Poultry Mite to Pyrethroids in France. Vet Rec 140: 577-579. doi:10.1136/vr.140.22.577.

Borne PM, Comte S (2003) Vacinas e Vacinação na produção avícola. Gessulli Guias, Porto Feliz, São Paulo.

Brännström S, Morrison DA, Mattsson JG, Chirico J (2008) Genetic differences in internal transcribed spacer 1 between Dermanyssus gallinae from wild birds and domestic chickens. Med Vet Entomol 22:152-155. doi:10.1111/j.1365-2915.2008.00722.x.

Campos DR, Avelar BR., Oliveira GF, Alves MSR, Borges DA, Medeiros MT, Scott FB (2017) Eficácia da associação de cipermetrina, clorpirifós, butóxido de piperonila e fluazuron contra larvas de Dermatobia hominis em bovinos naturalmente infestados. Braz J Vet Med 39: 28-32. 
Casida JE, Gammon DW, Glickman AH, Lawrence LJ (1983) Mechanisms of Selective Action of Pyrethroids Insecticides. Ann Rev Pharmacol Toxicol 23: 413-438. doi:10.1146/annurev.pa.23.040183.002213.

Cencek T, Karamon J, Sroka J, Zdybel J (2011) New in Vitro Method for Determination of Acaricide efficiency against Dermanyssus gallinae mites. Bull Vet Inst Pulawy 55: 657-662.

Chauve C (1998) The poultry red mite Dermanyssus gallinae (De Geer, 1778): current situation and future prospects for control. Vet parasitol 79: 239-245. doi:10.1016/s0304-4017(98)00167-8.

Cunha LM (2013) Aspectos epidemiológicos relacionados à ocorrência de ácaros hematófagos em granjas comerciais de postura no Estado de Minas Gerais e avaliação de armadilhas para captura de Dermanyssus gallinae (ACARI: DERMANYSSIDAE) (DE GEER, 1778). PhD dissertation, Universidade Federal de Minas Gerais. http://hdl.handle.net/1843/BUBD-9BGJZE

Cunha LM, Cunha MM, Leite RC, Silva IJ, Oliveira PR. (2009) Comparação da eficiência de diferentes armadilhas utilizadas para a captura de Dermanyssus gallinae (Acari: Dermanyssidae) (de Geer, 1778). Rev Bras Parasitol Vet 18: 59-62. doi:10.4322/rbpv.01804011.

Eraslan G, Tekeli MY, Karabacak M (2017) Toxicokinetic of cypermethrin in broiler chickens. Fresenius Environ Bull 26: 4704-4710

Faleiro DCC (2012) Ácaros associados a ninhos abandonados por pássaros e a aves de postura de ovos comerciais, no Vale do Taquari, Rio Grande do Sul. PhD dissertation, Universidade do Vale do Taquari Univates. http://hdl.handle.net/10737/280.

Faleiro DCC, Toldi M, Da Silva GL, Ferla NJ (2015) The ectoparasites Dermanyssus gallinae and Megninia ginglymura: bioecology and natural enemies in commercial egg-laying hens. Syst Appl Acarol 20: 861-874. doi:10.11158/saa.20.8.3.

Flochlay AS, Thomas E, Sparagano O (2017) Poultry red mite (Dermanyssus gallinae) infestation: a broad impact parasitological disease that still remains a significant challenge for the egg-laying industry in Europe. Parasites Vectors 10: 1-6. doi:10.1186/s13071-017-2292-4.

Gay M, Lempereur L, Francis F, Megido RC (2020) Control of Dermanyssus gallinae (De Geer 1778) and other mites with volatile organic compounds, a review. Parasitology, 147: 731-739. doi:10.1017/S0031182020000530.

Harrington DWJ, George DR, Guy JH, Sparagano OAE (2011) Opportunities for integrated pest management to control the poultry red mite, Dermanyssus gallinae. Worlds Poult Sci J 67: 83-94. doi:10.1017/S0043933911000079.

Horn TB, Korbes JH, Granich J, Senter M, Ferla NJ (2016) Influence of laying hen systems on the mite fauna (Acari) community of commercial poultry farms in southern Brazil. Parasitol Res 115: 355-366. doi:10.1007/s00436-015-4756-9. 
322

323

324

325

326

327

328

329

330

331

332

333

334

335

336

337

338

339

340

341

342

343

344

345

346

347

348

349

350

351

352

353

354

Kim SI, Na YE, Yi JH, Kim BS, Ahn YJ (2007) Contact and fumigant toxicity of oriental medicinal plant extracts against Dermanyssus gallinae (Acari: Dermanyssidae). Vet Parasitol 145: 377-382. doi:10.1016/j.vetpar.2006.12.021.

Locher N, Al-Rasheid KA, Abdel-Ghaffar F, Mehlhorn H (2010) In vitro and field studies on the contact and fumigant toxicity of a neem-product (Mite-Stop ${ }^{\circledR}$ ) against the developmental stages of the poultry red mite Dermanyssus gallinae. Parasitol Res 107: 417-423. doi:10.1007/s00436-010-1882-2.

Marangi M, Cafiero MA, Capelli G, Camarda A, Sparagano OAE, Giangaspero A (2009) Evaluation of the poultry red mite, Dermanyssus gallinae (Acari: Dermanyssidae) susceptibility to some acaricides in field populations from Italy. Exp Appl Acarol 48:143-155. doi:10.1007/s10493-008-9224-0.

Moro CV, De Luna CJ, Tod A, Guy JH (2009) The poultry red mite (Dermanyssus gallinae): a potential vector of pathogenic agents. In: Control of Poultry Mites (Dermanyssus). Springer, Dordrecht, 93-104.

Mul M, Van Niekerk T, Chirico J, Maurer V, Kilpinen O, Sparagano OAE (2009) Control methods for Dermanyssus gallinae in systems for laying hens: results of an international seminar. Worlds Poult Sci J 65: 589-600. doi:10.1017/S0043933909000403.

Nordenfors H, Hoglund J (2000) Long term dynamics of Dermanyssus gallinae in relation to mite control measures in aviary systems for layers. Br. Poult. Sci. 41: 533-540. doi:10.1080/713654991.

Nordenfors H, Hoglund J, Uggla A (1999) Effects of temperature and humidity on oviposition, molting, and longevity of Dermanyssus gallinae (Acari: Dermanyssidae). J Med Entomol 36: 68- 72. doi:10.1093/jmedent/36.1.68.

Oliveira TM (2017) Caracterização epidemiológica e avaliação de risco associada a presença de ectoparasitos em granjas de postura comercial em Minas Gerais. PhD dissertation, Universidade Federal de Minas Gerais. http://hdl.handle.net/1843/SMOC-AKGPFG.

Ouro fino (2020) Colosso Avicultura.

https://www.ourofinosaudeanimal.com/produtos/aves/ectoparasiticidas/colosso-avicultura/ Accessed 15 December 2020.

Pereira DMC (2011) Dermanyssus gallinae em galinhas poedeiras em bateria: carga parasitária, acção vectorial e ensaio de campo de um biopesticida. PhD dissertation, Universidade Técnica de Lisboa. http://hdl.handle.net/10400.5/3571.

Rezende LDC, Cunha LM, Teixeira CM, Oliveira PRD, Martins NRDS (2013) Ácaros de importância para a avicultura de postura: algumas considerações aplicadas à realidade da indústria avícola brasileira. Ciência Rural 43: 1230-1237. doi:10.1590/S0103-84782013005000088.

Roy L, Chauve C, Delaporte J, Inizan G, Buronfosse T (2009) Exploration of the susceptibility of AChE from the poultry red mite Dermanyssus Gallinae (Acari: Mesostigmata) to Organophosphates in Field 
355 isolates from France. In control of poultry mites (Dermanyssus), edited by O. A. E. Sparagano, 19-30.

356 Dordrecht: Springer. doi:10.1007/978-90-481-2731-3_4.

357 Sequeira TCGO, Amorim RM, Borges AS, Brant MPRC (2014) Eficácia terapêutica e residual de seis

358 formulações inseticidas sobre o parasitismo por larvas de dermatobia hominis em bovinos. Vet Zootec

359 21:177-186. http://hdl.handle.net/11449/141075.

360 Silva WC, Ribeiro JD, Souza HEM, Corrêa RS (2007) Atividade inseticida de Piper aduncum L.

361 (Piperaceae) sobre Aetalion sp. (Hemiptera: Aetalionidae), praga de importância econômica no

362 Amazonas. Acta Amazônica 37: 293-298. doi:10.1590/S0044-59672007000200017.

363 Sparagano O, George DR, Harrington DWJ, Giangaspero A (2014) Significance and control of the

364 poultry red mite, Dermanyssus gallinae. Annu Rev Entomol 59:447-466. doi:10.1146/annurev-ento-

365 011613-162101.

366 Sparagano O, Aleksander P, Murano T, Camarda A, Sahibi H, Kilpinen O, Mul M, Emous R, Bouquin S,

367 Hoel K, Cafiero MA (2009) Prevalence and key figures for the poultry red mite Dermanyssus gallinae

368 infections in poultry farm systems. Exp Appl Acarol 48:3-10. doi:10.1007/978-90-481-2731-3_2.

369 Taylor MA (2001) Recent developments in ectoparasiticides. Vet J 161: 253-268.

370 doi:10.1053/tvj1.2000.0549.

371 Taylor MA, Coop RL, Wall RL (2007) Vet Parasitol 3rd edn. Blackwell Publishing, London, UK.

372 Theseo (2007) Désinfectant bactéricide, virucide, acaricide et insecticide. Fiche Technique.

373 https://www.hyprodis.fr/F-FICHIER_LIE_A_1024.pdf-mefisto-shock.aspx. Acessed 16 December 2020.

374 Thomas E, Zoller H, Liebisch G, Alves LFA, Vettorato L, Chiummo RM, Sigognault-Flochlay A (2018)

375 In vitro activity of fluralaner and commonly used acaricides against Dermanyssus gallinae isolates from

376 Europe and Brazil. Parasites Vectors 11: 361. doi:10.1186/s13071-018-2956-8.

377 Tucci EC, Prado AP, Araujo RP (2008) Thermal requirements of Dermanyssus gallinae (De Geer, 1778)

378 (Acari: Dermanyssidae). Rev Bras Parasitol Vet (Online) 17: 67-72. doi:10.1590/S1984-

37929612008000200002.

380 Valiente-Moro C, Chauve CM, Zenner L (2005) Vectorial role of some dermanyssoid mites (Acari,

381 Mesostigmata, Dermanyssoidea). Parasite 12: 99-109. doi: 10.1051/parasite/2005122099

382 Valiente-Moro C, Chauve CM, Zenner L (2007) Experimental infection of Salmonella Enteritidis by the

383 poultry red mite, Dermanyssus gallinae. Vet parasitol 146: 329-336. Doi: 10.1016/j.vetpar.2007.02.024. 